\title{
Extremely low-oxygen storage: aerobic, anaerobic metabolism and overall quality of apples at two temperatures
}

\author{
Vagner Ludwigi,* (D), Fabio Rodrigo Thewes ${ }^{1}$ (D), Lucas Mallmann Wendt ${ }^{1}$ (D), Magno Roberto Pasquetti \\ Berghetti $^{1}$ (D), Erani Eliseu Schultz ${ }^{1}$ (D), Suele Fernanda Prediger Schmidt ${ }^{1}$ (D), Auri Brackmann ${ }^{1}$ (D) \\ 1. Universidade Federal de Santa Maria - Departamento de Fitotecnia - Núcleo de Pesquisa em Pós-Colheita - Santa \\ Maria - Santa Maria (RS), Brazil.
}

\begin{abstract}
The objective of this work was to evaluate the effect of extremely low-oxygen storage on the aerobic, anaerobic metabolism and overall quality maintenance of 'Royal Gala' and 'Galaxy' apples stored at two temperatures. For 'Royal Gala' apples, four treatments were evaluated in a two-factor scheme $(2 \times 2)$, with two storage conditions: $[1] 1.2 \mathrm{kPaO}_{2}+2 \mathrm{kPaCO}_{2}$; [2] $0.8 \mathrm{kPaO} \mathrm{O}_{2}+1.6 \mathrm{kPa} \mathrm{CO}$; and two temperatures $\left(1.0\right.$ and $\left.1.5^{\circ} \mathrm{C}\right)$. For 'Galaxy' apples, the experiment was conducted in a two-factor $(3 \times 2)$ scheme with three storage conditions: [1] $1.2 \mathrm{kPaO}_{2}+2 \mathrm{kPa} \mathrm{CO}$; [2] $0.8 \mathrm{kPaO}_{2}+1.6 \mathrm{kPa} \mathrm{CO}_{2}$; [3] $0.4 \mathrm{kPa} \mathrm{O}_{2}+1.2 \mathrm{kPa} \mathrm{CO}_{2}$, and two temperatures $\left(1.0\right.$ and $\left.1.5^{\circ} \mathrm{C}\right)$. The 'Royal Gala' apples stored under $0.8 \mathrm{kPaO}_{2}+1.6 \mathrm{kPa} \mathrm{CO}_{2}$ at $1.5^{\circ} \mathrm{C}$ had higher flesh firmness, healthy fruit and soluble solids along with lower incidence of flesh breakdown and mealiness. The 'Galaxy' apples stored under $0.4 \mathrm{kPaO}_{2}+1.2 \mathrm{kPa} \mathrm{CO}_{2}$, at temperature of $1.5^{\circ} \mathrm{C}$ had lower 1-carboxylic acid-1-aminocyclopropane (ACC) oxidase enzyme activity, ethylene production, occurrence of mealiness, when compared to $1.0^{\circ} \mathrm{C}$. The storage of these two cultivars at $1.5^{\circ} \mathrm{C}$ with extremely low $\mathrm{O}_{2}$ partial pressures is possible. The possibility to increase the storage temperature from $1^{\circ} \mathrm{C}$, which is traditionally used for these mutants, to $1.5^{\circ} \mathrm{C}$ allows to keep better quality with the advantage of energy saving.
\end{abstract}

Key words: controlled atmosphere, food preservation and safety, post harvest fruit, shelf life.
Received:

Dec. 15, 2019

Accepted:

Apr. 14, 2020

Section Editor:

Daniel Alexandre Neuwald

${ }^{\star}$ Corresponding author:

vagnerludwig2012@hotmail.com

\section{INTRODUCTION}

Most apples produced in Brazil belong to the 'Gala' cultivar and its spontaneous mutants, including 'Galaxy' and 'Royal Gala, totalizing a production of 326,658 $\mathrm{t}$ in 2017/2018 crop, representing $66 \%$ of the national apple production (Agapomi 2018). These mutants stand out for presenting a good red coloration of epidermis (Brackmann et al. 2009, 2012; Weber et al. 2013), high juiciness and better balance between acidity and soluble solids (Thewes et al. 2015).

Temperature is the most important factor for the maintenance of fruit quality during storage (Both et al. 2018; Brackmann et al. 2008). The reduction in temperature suppresses the respiratory pathway, ethylene production and, consequently, the reduction of biochemical changes in the fruit (Kruse et al. 2011; Saltveit 1999; Steffens et al. 2007). The ideal temperature for controlled atmosphere storage of 'Gala' apples and their mutants ranges from 0.0 to $1.0^{\circ} \mathrm{C}$ (Both et al. 2017; Brackmann et al. 2009; Thewes et al. 2017a). However, recent studies reported the possibility of increasing the storage temperature of some types of apples without quality losses (Anese et al. 2019; Weber et al. 2019). The application of 1-methylcyclopropene (1-MCP) to apples stored under controlled atmosphere (CA) allowed an increase of the storage temperature to $2.5^{\circ} \mathrm{C}$, obtaining an electrical energy saving of 26 and 35\% for the 'Jonagold' and 'Gala' apples, respectively (Kittemann et al. 2015). The use of dynamic controlled atmosphere by chlorophyll fluorescence (DCA-CF) allowed 20\% of energy savings in apples stored for seven months (Kittemann et al. 2015). In both studies, the increase in temperature did not result in 
fruit quality losses; however, quality maintenance varied among cultivars and some were more sensitive to the increase in temperature. Apple cultivars respond differently to the increase in temperature and the auxiliary technique adopted, such as the application of 1-MCP, DCA-CF and ultra-low oxygen (ULO) (Köpcke 2015). The increase of $\mathrm{O}_{2}$ partial pressure in the storage room cause an increase in the fruit metabolism, resulting in a lower quality maintenance (Steffens et al. 2007). Therefore, it is important to conduct studies to verify the feasibility to increase the storage temperature and its interaction with extremely low $\mathrm{O}_{2}$ partial pressures in maintaining fruit quality.

The most widely used method for the storage of apples in Brazil is CA (Brackmann et al. 2012; Weber et al. 2013). Thus, $\mathrm{O}_{2}$ partial pressure are reduced, $\mathrm{CO}_{2}$ partial pressure increased, storage temperature reduced and relative humidity increased to levels close to $100 \%$ inside the rooms, in order to reduce respiration and ethylene production (Gorny and Kader 1996; Ke et al. 1991; Lumpkin et al. 2015). The fruit tolerance to CA depends on several factors such as cultivar, maturation stage, harvest year, $\mathrm{O}_{2}$ and $\mathrm{CO}_{2}$ partial pressure and duration of storage (Bulens et al. 2012; Watkins 2008). Regarding the storage in CA, $\mathrm{O}_{2}$ partial pressure is maintained above the anaerobic compensation point, which consists of the $\mathrm{O}_{2}$ concentration that causes lower production of $\mathrm{CO}_{2}$ in the storage chamber (Boersig et al. 1988), consequently the fruit are not at the point of minimum respiration. This causes quality losses, such as low flesh firmness, decrease of aroma (Thewes et al. 2015) and increase in decay incidence after storage under refrigerated atmosphere (RA) and CA (Antoniolli et al. 2011).

The ULO storage consists in maintaining $\mathrm{O}_{2}$ partial pressure below $1.0 \mathrm{kPa}$, thus keeping the metabolism of the fruit closer to the $\mathrm{O}_{2}$ minimum limit, which favors a greater maintenance of the postharvest quality of apples. The storage of apples in low $\mathrm{O}_{2}$ reduces the oxidative metabolism, the 1-carboxylic acid-1-aminocyclopropane (ACC) oxidase enzyme activity and ethylene production (Bekele et al. 2016; Imahori et al. 2013; Mditshwa et al. 2017; Thewes et al. 2015). 'Fuji' apples stored at $2.5^{\circ} \mathrm{C}$ under 0.7 to $1.0 \mathrm{kPa}$ of $\mathrm{O}_{2}$ had lower flesh firmness loss and lower physiological disorders incidence when compared to the $\mathrm{O}_{2}$ partial pressures of 2.0 and $3.0 \mathrm{kPa}$ (Argenta and Brackmann 1994). 'Royal Gala' apples stored in DCA-RQ with $\mathrm{O}_{2}$ partial pressure between 0.13 and $0.41 \mathrm{kPa}$ presented higher flesh firmness, higher percentage of healthy fruit and lower incidence of physiological disorders as compared to CA with $1.2 \mathrm{kPa} \mathrm{O}_{2}+2.0 \mathrm{kPa} \mathrm{CO}_{2}$ (Both et al. 2017).

The objective of this work was to evaluate the effect of extremely low-oxygen storage on the aerobic, anaerobic metabolism and overall quality maintenance of 'Royal Gala' and 'Galaxy' apples stored at two temperatures.

\section{MATERIAL AND METHODS}

\section{Experimental material, establishment and monitoring of CA conditions}

After harvest, the apples were selected by discarding those with decay, inadequate size or mechanical damage. Each treatment was composed of four replicates of 25 fruit and the design was completely randomized. For 'Royal Gala' apples, 4 treatments were carried out in a factorial scheme $(2 \times 2)$, with two atmosphere conditions: [1] $1.2 \mathrm{kPa} \mathrm{O}_{2}+$ $2.0 \mathrm{kPa} \mathrm{CO}_{2} ;[2] 0.8 \mathrm{kPa} \mathrm{O}_{2}+1.6 \mathrm{kPa} \mathrm{CO}_{2}$; and two temperatures $\left(1.0\right.$ and $\left.1.5^{\circ} \mathrm{C}\right)$ (Both et al. 2017; Brackmann et al. 2009). For 'Galaxy' apples, a bifactorial scheme $(3 \times 2)$ was used, with three atmosphere conditions [1] $1.2 \mathrm{kPa} \mathrm{O}_{2}+2.0 \mathrm{kPa} \mathrm{CO}_{2}$; [2] $0.8 \mathrm{kPa} \mathrm{O}_{2}+1.6 \mathrm{kPa} \mathrm{CO}_{2 ;}$ [3] $0.4 \mathrm{kPa} \mathrm{O}_{2}+1.2 \mathrm{kPa} \mathrm{CO}_{2,}$ and two temperatures $\left(1.0\right.$ and $\left.1.5^{\circ} \mathrm{C}\right)$.

In order to establish the atmosphere conditions, the fruit were stored in hermetically sealed chambers, with a volume of $0.233 \mathrm{~m}^{3}$, which were allocated inside cold rooms, and the storage temperature was set according to each treatment. The $\mathrm{O}_{2}$ partial pressure was reduced by using $\mathrm{N}_{2}$ from a nitrogen generator that uses the pressure swing adsorption principle (PSA) to sweep and dilute the $\mathrm{O}_{2}$ inside the chambers. The $\mathrm{O}_{2}$ was reduced to $5.0 \mathrm{kPa}$ on the first day of storage and $1.0 \mathrm{kPa} \cdot \mathrm{day}^{-1}$ on the following five days through fruit respiration and $\mathrm{N}_{2}$ flushing, until the preestablished partial pressure for each treatment was reached. The partial pressures of $\mathrm{CO}_{2}$ in the chambers were obtained by their accumulation from fruit respiration. The replacement of $\mathrm{O}_{2}$ consumed by the fruit was carried out by injecting cold atmospheric air with an automatic control system. The excess $\mathrm{CO}_{2}$ produced by fruit respiration was absorbed by the circulation of the gas in the chamber through a $\mathrm{CO}_{2}$ absorber with calcium hydroxide. The CA conditions were measured daily and corrected by an automatic control system (Valis, Lajeado, RS, Brazil) connected to an $\mathrm{O}_{2}$ and $\mathrm{CO}_{2}$ analyzer (Siemens, model Ultramat 23, Germany). 


\section{Analysis of fruit quality and metabolism}

The laboratory analyses were performed after nine months of storage plus seven days of shelf life at $20^{\circ} \mathrm{C}( \pm 1.0)$. The following parameters were analyzed:

\section{Ethylene production}

Determined by stowing of $1.5 \mathrm{~kg}$ sample in a $5 \mathrm{~L}$ container, which was hermetically closed for about $1 \mathrm{~h}$. After, two samples of $1 \mathrm{~mL}$ of the headspace were taken from the container and injected into a gas chromatograph, with a Poropak $\mathrm{N} 80100$ column and flame ionization detector (FID), with column, injector and detector temperature of 90,140 and $200{ }^{\circ} \mathrm{C}$, respectively. The results were expressed in $\mathrm{ng}_{2} \mathrm{H}_{4} \cdot \mathrm{kg}^{-1} \cdot \mathrm{s}^{-1}$.

\section{Respiration rate}

Determined by stowing of $1.5 \mathrm{~kg}$ sample in a $5 \mathrm{~L}$ container, which was hermetically closed for about $1 \mathrm{~h}$, headspace air was flushed through an Isocell Oxicarb $\mathrm{CO}_{2}$ analyzer, to determine the $\mathrm{CO}_{2}$ concentration. The results were expressed in $\mu \mathrm{g} \mathrm{CO}_{2} \cdot \mathrm{kg}^{-1} \cdot \mathrm{s}^{-1}$.

Internal ethylene and internal $\mathrm{CO}_{2}$

Determined according to methodology proposed by Thewes et al. (2015). Results were expressed in $\mu \mathrm{g} \cdot \mathrm{L}^{-1}$ and $\mathrm{mg} \cdot 100 \mathrm{~mL} \mathrm{~L}^{-1}$, respectively.

\section{ACC oxidase enzyme activity}

Determined from samples of the epidermis $(3 \mathrm{~g})$ collected from the equatorial region of the fruit. These samples were immersed in a solution containing $0.1 \mathrm{mmol} \cdot \mathrm{L}^{-1} \mathrm{ACC}$ and in a 2-(N-morpholino) ethanesulfonic acid (MES) buffer solution with a $6.0 \mathrm{pH}$. After $30 \mathrm{~min}$, the samples were withdrawn and placed in $50 \mathrm{~mL}$ hermetically sealed syringes, to which $1 \mathrm{~mL}$ of $\mathrm{CO}_{2}$ was added. After $30 \mathrm{~min}$, the concentration of ethylene contained in the syringes was determined by the same chromatograph used to determine ethylene production. Data was expressed in $\mathrm{ng} \mathrm{C}_{2} \mathrm{H}_{4} \cdot \mathrm{kg}^{-1} \cdot \mathrm{s}^{-1}$, according to Bufler (1986).

\section{Flesh firmness}

Determined with a penetrometer equipped with a $11 \mathrm{~mm}$ tip inserted on two opposite sides in the equatorial region of the fruit, from where the epidermis have been previously removed. The data were expressed in Newton $(\mathrm{N})$.

\section{Soluble solids and titratable acidity}

Soluble solids (SS) were determined with the aid of a refractometer, from the juice extracted from the samples. The results were expressed in percentage. Titratable acidity was obtained by titration with $0.1 \mathrm{~N} \mathrm{NaOH}$, of a solution containing $10 \mathrm{~mL}$ of juice diluted in $100 \mathrm{~mL}$ of distilled water, until the $\mathrm{pH}$ of 8.1 . Results were expressed as g malic acid $\cdot 100 \mathrm{~g}^{-1}$.

\section{Physiological disorders, decay incidence and healthy fruit amount}

Determined by counting fruit that presented external and/or internal symptoms such as flesh breakdown, mealiness, decay and pulp cracking, according to Thewes et al. (2015). The health fruit was quantified by the difference among the 
total number of fruit and fruit with any symptom of decay, mealiness and incidence of flesh breakdown. The results were expressed in percentage of fruit affected.

Acetaldehyde, ethanol and ethyl acetate

Slices of equatorial region of the fruit were taken and centrifuged with a juicer Philips Walita centrifuge to extract the juice. Subsequently, $10 \mathrm{~mL}$ of the juice was packed in $20 \mathrm{~mL}$ vials. The juice sample was kept exposed in a water bath at $70^{\circ} \mathrm{C}$ for $30 \mathrm{~min}$, so that the anaerobic metabolism compounds could volatilize into the headspace of the vial. Afterwards, a $100 \mu \mathrm{L}$ sample of headspace air was injected into a gas chromatograph equipped with a $60 \mathrm{~m}$ long capillary column (DN-WAX Dani). The injector, column and detector temperatures were 180,60 and $250^{\circ} \mathrm{C}$, respectively. The results were expressed in $\mu \mathrm{L} \cdot \mathrm{L}^{-1}$.

\section{Statistical analysis}

Analysis of variance (ANOVA) was performed for each variable. The means were compared by Tukey's test with a 5\% probability of error, using the statistical software SISVAR version 5.6. The data that presented significant difference by ANOVA were submitted to partial least square (PLS) analysis, before the data were auto-scaled in order to obtain the same weights for all variables (mean $=0$ and variance $=1$ ). The Unscrambler X software (version 9.7, CAMO A/S, Trondheim, Norway) was used.

\section{RESULTS AND DISCUSSION}

\section{Partial least square (PLS)}

The PLS analysis allowed an overview of the experiment and correlated the influence of the storage conditions to the analyzed parameters. For 'Royal Gala' apples, the increase in storage temperature was found to be correlated to a higher concentration of soluble solids, greater percentage of healthy fruit, higher concentration of ethanol and ethyl acetate (Fig. 1a). On the other hand, the higher activity of the ACC oxidase enzyme, ethylene production at chamber opening and at 7 days of shelf life, as well as the internal ethylene concentration and respiration rate at 7 days, presented a correlation with the storage condition of $1.2 \mathrm{kPaO}_{2}+2.0 \mathrm{kPa} \mathrm{CO}_{2}$. For 'Royal Gala' apples the respiration rate was correlated to $1.0 \mathrm{kPa}_{2}+$ $2.0 \mathrm{kPa} \mathrm{CO}_{2}$ (Both et al. 2014a). The storage under $0.8 \mathrm{kPa} \mathrm{O}_{2}+1.6 \mathrm{kPa} \mathrm{CO}_{2}$ was correlated with the internal concentration of $\mathrm{CO}_{2}$ and respiration rate at chambers opening. For 'Galaxy' apples, the concentration of ethanol and internal $\mathrm{CO}_{2}$ presented an association to the storage under higher temperature (Fig. 1b). According to Both et al. (2018), storage of 'Galaxy' apples at $2.0^{\circ} \mathrm{C}$ resulted in higher ethanol concentration than at $1.0{ }^{\circ} \mathrm{C}$. The storage with $1.2 \mathrm{kPa} \mathrm{O}_{2}+2.0 \mathrm{kPa} \mathrm{CO}_{2}$ was correlated to the higher production of ethylene at chambers opening and at 7 days of shelf life, internal ethylene concentration, ACC oxidase enzyme activity and mealiness. In contrast, fruit stored under $0.4 \mathrm{kPa}_{2}+1.2 \mathrm{kPa} \mathrm{CO}_{2}$ and $0.8 \mathrm{kPa} \mathrm{O}_{2}+1.6 \mathrm{kPaCO}_{2}$ had a correlation to flesh firmness, healthy fruit, titratable acidity, acetaldehyde concentration, decay, pulp cracking and flesh breakdown, fact that did not lead to these treatments having a lower healthy fruit percentage (Fig. 2).

\section{Ethylene production, respiration rate, ACC oxidase activity and internal ethylene concentration}

'Royal Gala' apples stored under $1.2 \mathrm{kPa} \mathrm{O}_{2}+2.0 \mathrm{kPa} \mathrm{CO}_{2}$ presented a higher ethylene production, after shelf life, when stored at $1.0^{\circ} \mathrm{C}$ when compared to $1.5^{\circ} \mathrm{C}$ (Fig. 3a). 'Galaxy' apples stored at $2.0^{\circ} \mathrm{C}$ had a higher ethylene production at seven days of shelf life compared to apples stored at temperatures of 1.0 and $1.5^{\circ} \mathrm{C}$. Storage under $0.8 \mathrm{kPa} \mathrm{O}_{2}+1.6 \mathrm{kPa} \mathrm{CO}_{2}$ condition produced less ethylene immediately after chambers opening and at seven days shelf life when compared to $1.2 \mathrm{kPaO}_{2}+1.2 \mathrm{kPaCO}_{2}$ (Fig. 3a). 'Galaxy' apples submitted to $0.4 \mathrm{kPa} \mathrm{O}_{2}+1.2 \mathrm{kPa} \mathrm{CO}_{2}$, regardless of temperature, had 

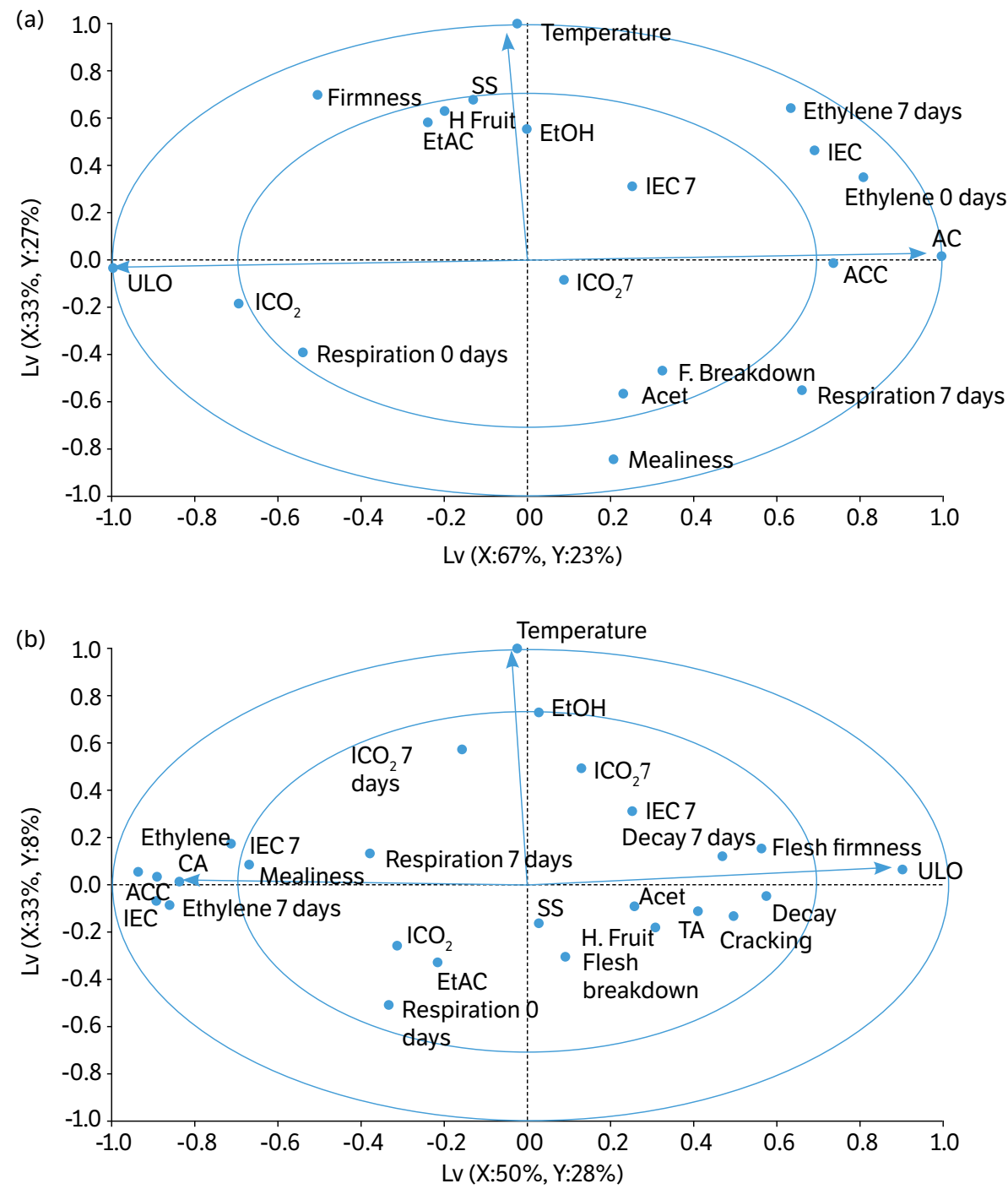

$\mathrm{ICO}_{2}$ : Internal concentration of $\mathrm{CO}_{2}$ at open chamber; $\mathrm{ICO}_{2}$ : Internal concentration of $\mathrm{CO}_{2}$ seven days at $20{ }^{\circ} \mathrm{C}$; ACC: 1 -carboxylic acid-1-aminocyclopropane oxidase enzyme activity; SS: soluble solids; TA: total acidity; IEC: internal concentration of ethylene; EtAC: ethyl acetate concentration; EtOH: ethanol concentration; Acet: acetaldehyde; $H$. fruits: Heathy fruits

Figure 1. (a) Scores of treatments (bold words) and correlations, the partial last square of 'Royal Gala' apples stored during nine months plus seven days at $20^{\circ} \mathrm{C}$; (b) scores of treatments (bold words) and correlations, the partial last square of 'Galaxy' apples stored during nine months plus seven days at $20^{\circ} \mathrm{C}$.

lower ethylene production compared to the $1.2 \mathrm{kPa} \mathrm{O}_{2}+2.0 \mathrm{kPa} \mathrm{CO}_{2}$ and $0.8 \mathrm{kPa} \mathrm{O}_{2}+1.6 \mathrm{kPa} \mathrm{CO}_{2}$ conditions, which may be explained by the lower ACC oxidase enzyme activity (Fig. 3a). For 'Galaxy' apples at chamber opening, fruit stored under $0.8 \mathrm{kPa} \mathrm{O}_{2}+1.6 \mathrm{kPa} \mathrm{CO}_{2}$ at $1.5^{\circ} \mathrm{C}$ had a lower ethylene production compared to $1.0^{\circ} \mathrm{C}$. Blueberries stored at $2{ }^{\circ} \mathrm{C}$ had higher ethylene production than storage at $10{ }^{\circ} \mathrm{C}$, probably the low temperature caused an abiotic stress increasing the ethylene production (Álvarez-Hernández et al. 2019). The ethylene production by fruit stored under $0.4 \mathrm{kPa}_{2}+$ $1.2 \mathrm{kPaCO}_{2}$ was not influenced by the storage temperature. Fruit stored under $1.2 \mathrm{kPa} \mathrm{O}_{2}+1.2 \mathrm{kPa} \mathrm{CO}_{2}$ showed higher concentration of ethylene compared to $0.4 \mathrm{kPa} \mathrm{O}_{2}+1.2 \mathrm{kPa} \mathrm{CO}_{2}$ and $0.8 \mathrm{kPa} \mathrm{O}_{2}+1.6 \mathrm{kPa} \mathrm{CO}_{2}$ (Fig. 3a). Fruit stored under $0.4 \mathrm{kPa} \mathrm{O}_{2}+1.2 \mathrm{kPa} \mathrm{CO}_{2}$, after seven days of shelf life, had a lower ethylene production than the fruit kept under $0.8 \mathrm{kPa} \mathrm{O}_{2}+1.6 \mathrm{kPa} \mathrm{CO}_{2}$, this may be explained by the lower activity of the ACC oxidase enzyme of fruit stored under $0.4 \mathrm{kPa}$ $\mathrm{O}_{2}+1.2 \mathrm{kPa} \mathrm{CO}_{2}$ at $1.5^{\circ} \mathrm{C}$ (Fig. 3a), similar results were found by Both et al. (2014b), Thewes et al. (2015), and Weber et al. (2013). The increased concentration of ethanol in the fruit can inhibit the ACC oxidase enzyme activity and the ethylene production (Thewes et al. 2015). It was observed that ethanol has a suppressive effect in the transcription genes 

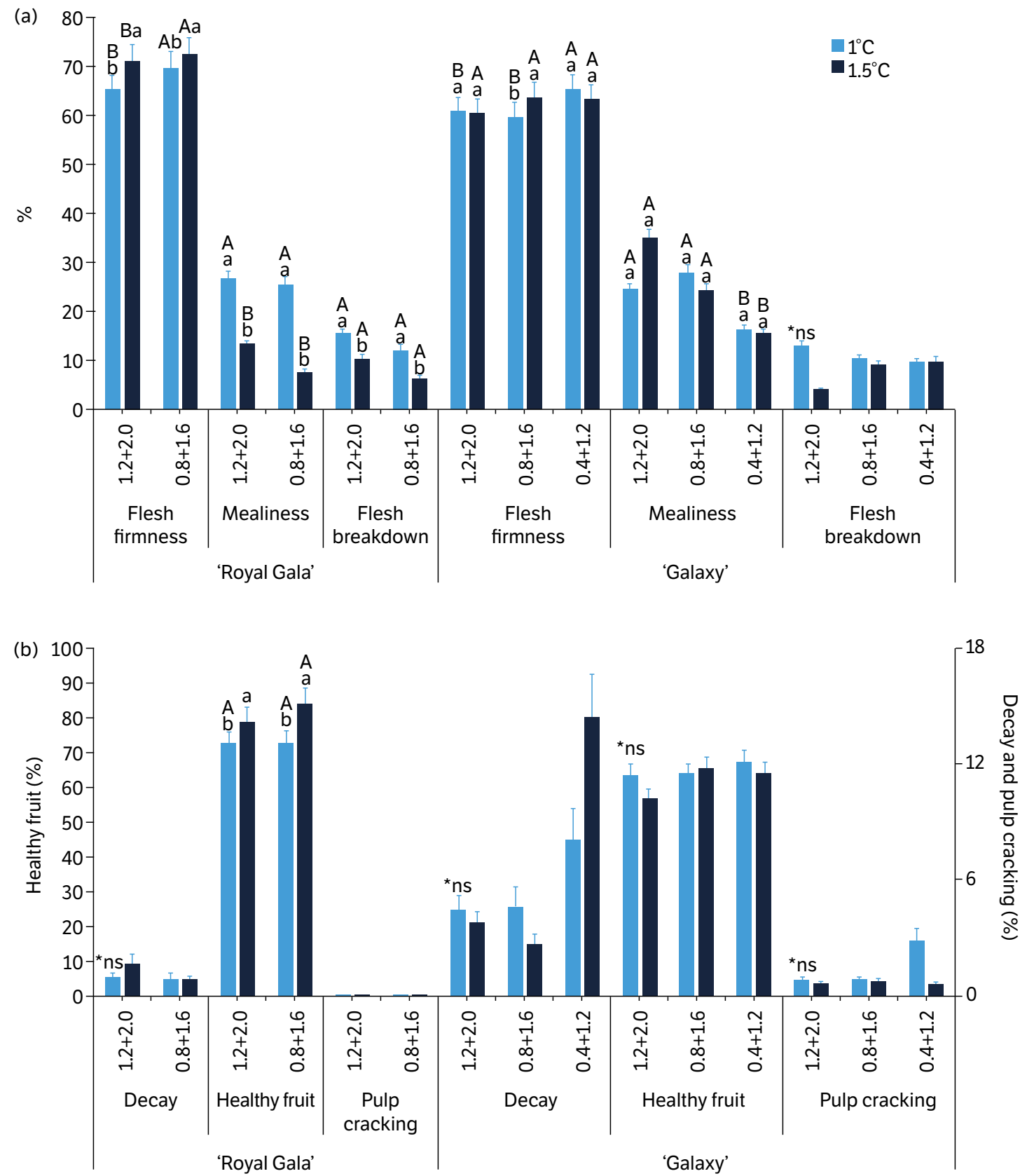

Note: Means followed by equals letters, lowercase in the atmosphere condition and uppercase in the temperature storage, do not differ by Tukey's test at $5 \%$ of error probability $(p<0.05)$. *ns: not significant difference.

Figure 2. (a) Flesh firmness, mealiness and flesh breakdown (b) decay, healthy fruit and pulp cracking of 'Royal Gala' and 'Galaxy' apples stored under ultralow oxygen in two temperatures during nine months plus seven days of shelf life.

of the ACC oxidase enzyme (BO-ACO1 e $B O-A C O 2)$ and, consequently, the production of ethylene in broccoli (Asoda et al. 2009; Podd and Van Staden 1998).

The respiration rate in 'Royal Gala' apples stored under $1.2 \mathrm{kPa} \mathrm{O}_{2}+2.0 \mathrm{kPa} \mathrm{CO}_{2}$ was lower than fruit stored under $0.8 \mathrm{kPa} \mathrm{O}_{2}+1.6 \mathrm{kPa} \mathrm{CO}_{2}$ at $1.0^{\circ} \mathrm{C}$ (Fig. 3b). Fruit stored under $0.8 \mathrm{kPa} \mathrm{O}_{2}+2.0 \mathrm{kPa} \mathrm{CO}_{2}$ must have suffered chilling injury, which increased their respiration rate, because when kept at $1.5^{\circ} \mathrm{C}$, no difference between $1.2 \mathrm{kPa} \mathrm{O}_{2}+2.0 \mathrm{kPa} \mathrm{CO}_{2}$ and $0.8 \mathrm{kPaO}_{2}+1.6 \mathrm{kPa} \mathrm{CO}_{2}$ was found. The oxygen lowering below $1.0 \mathrm{kPa}$ causes an increase in the respiration rate, if they are submitted to low temperatures (Brackmann et al. 2008). After 7 days of shelf life, no difference in the respiration rate was found between the fruit stored under $1.2 \mathrm{kPa} \mathrm{O}_{2}+2.0 \mathrm{kPa} \mathrm{CO}_{2}$ and $0.8 \mathrm{kPa} \mathrm{O}_{2}+1.2 \mathrm{kPa} \mathrm{CO}_{2}$, at $1.0{ }^{\circ} \mathrm{C}$. When the 


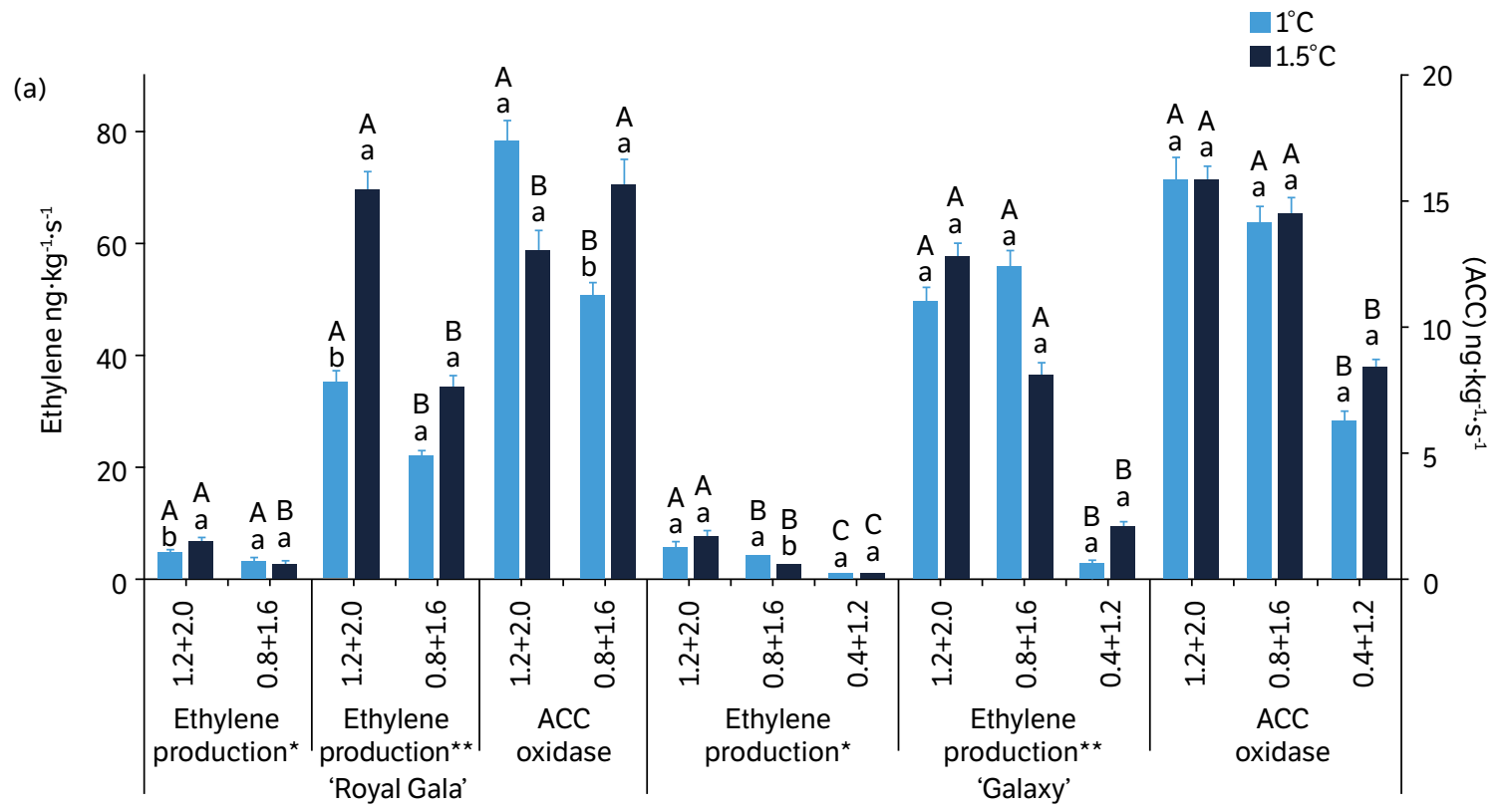

(b)

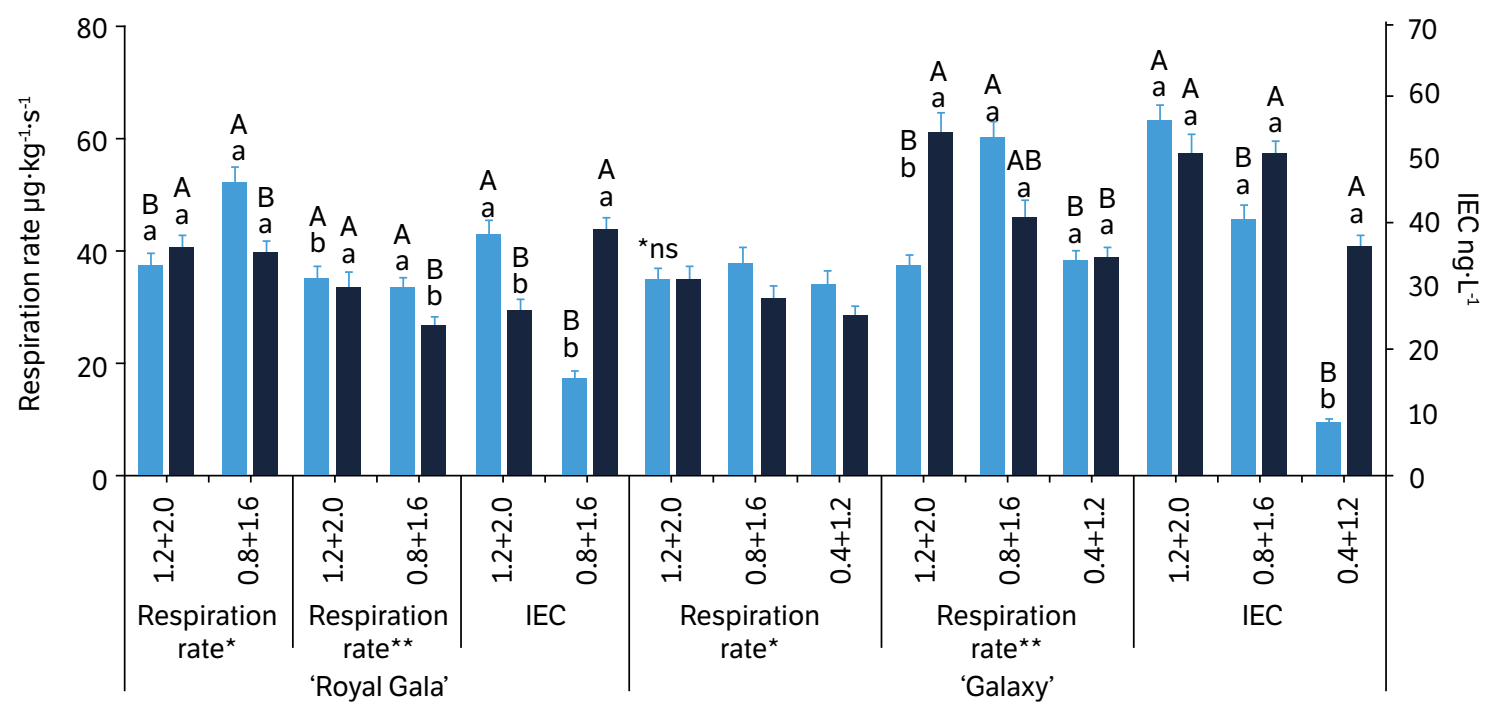

Note: Means followed by equals letters, lowercase in the atmosphere condition and uppercase in the temperature storage, do not differ by Tukey's test at $5 \%$ of error probability $(p<0.05)$. ${ }^{*}$ Chamber open; ${ }^{* *}$ after shelf life; * $n s:$ not significant difference.

Figure 3. (a) Ethylene production and ACC oxidase, (b) respiration rate and IEC of 'Royal Gala' and 'Galaxy' apples stored under ultralow oxygen in two temperatures during nine months plus seven days of shelf life.

temperature was raised to $1.5^{\circ} \mathrm{C}$, the fruit stored under $0.8 \mathrm{kPa} \mathrm{O}_{2}+1.2 \mathrm{kPa} \mathrm{CO}_{2}$ maintained lower respiration rate as compared to $1.2 \mathrm{kPaO}_{2}+2.0 \mathrm{kPa} \mathrm{CO}_{2}$ (Fig. 3b). For 'Galaxy', at 7 days of shelf life, the condition $1.5{ }^{\circ} \mathrm{C}$ and $1.2 \mathrm{kPa} \mathrm{O}_{2}$ $+2.0 \mathrm{kPaCO}$ resulted in higher fruit respiration rate than the ones stored under $0.4 \mathrm{kPa} \mathrm{O}_{2}+1.2 \mathrm{kPa} \mathrm{CO}_{2}$. However, the temperature elevation did not increase the respiration rate of fruit stored under $0.4 \mathrm{kPa} \mathrm{O}_{2}+1.2 \mathrm{kPaCO}_{2}$, evidencing the effect of the ethanol production increase (Fig. $4 \mathrm{~b}$ ) in the reduction of ethylene production and, consequently, a reduction in the respiration rate. When the fruit were stored at $1.0^{\circ} \mathrm{C}$, the respiration rate was greater in the fruit stored under $0.8 \mathrm{kPa} \mathrm{O}_{2}$ $+1.6 \mathrm{kPa} \mathrm{CO}$ when compared to all other conditions (Fig. 3b).

The internal ethylene concentration (IEC) in 'Royal Gala', at chamber opening, was lower under $0.8 \mathrm{kPa} \mathrm{O}_{2}+1.6 \mathrm{kPa}$ $\mathrm{CO}_{2}$ when compared to $1.2 \mathrm{kPa} \mathrm{O}_{2}+2.0 \mathrm{kPa} \mathrm{CO}_{2}$ at $1.0^{\circ} \mathrm{C}$ (Fig. 3b). This finding may be related to the lower respiratory 

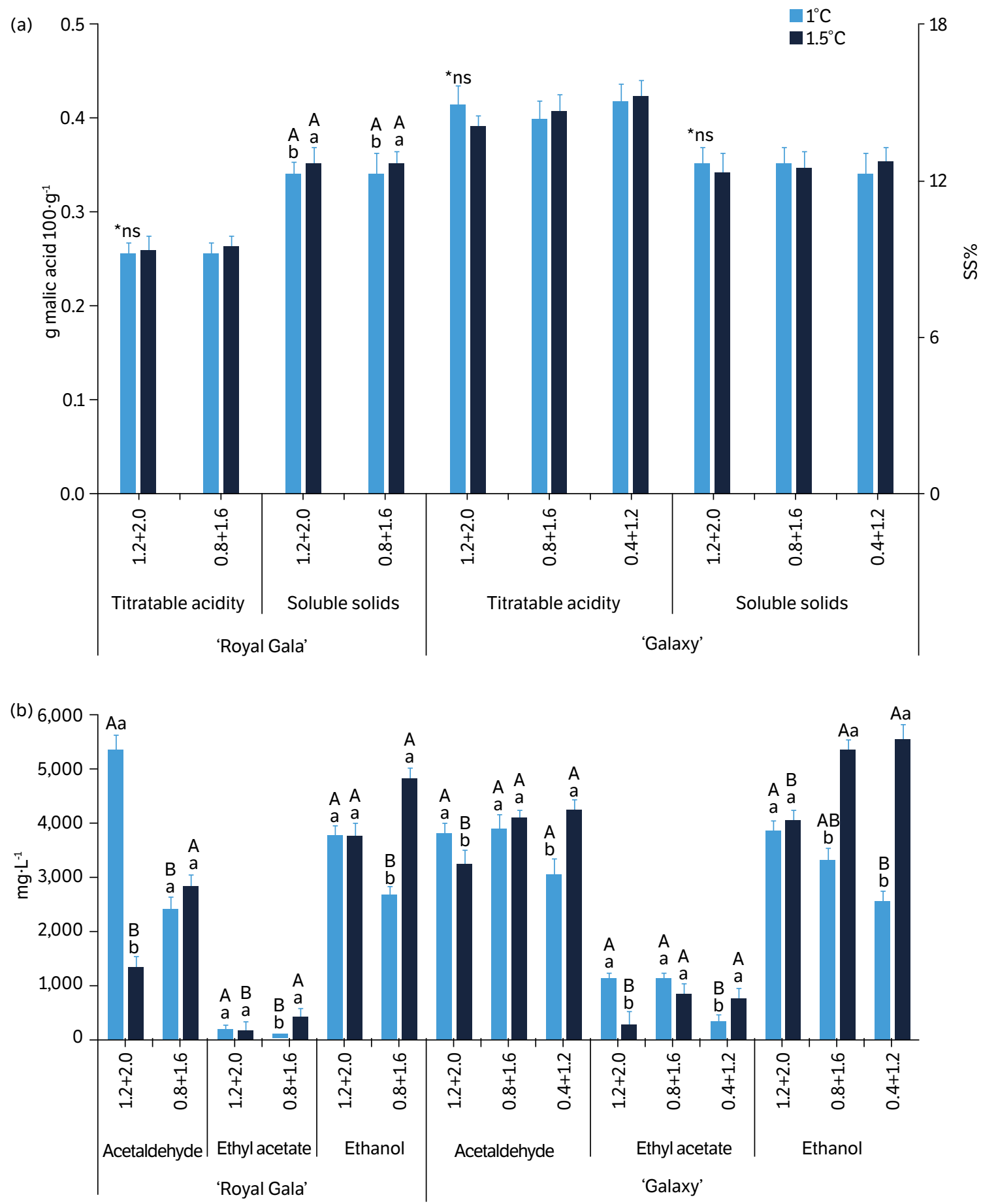

Means followed by equals letters, lowercase in the atmosphere condition and uppercase in the temperature storage, do not differ by Tukey's test at $5 \%$ of error probability $(p<0.05)$. *ns: not significant difference.

Figure 4. (a) Titratable acidity, soluble solids; (b) acetaldehyde, ethyl acetate and ethanol concentration of 'Royal Gala' and 'Galaxy' apples stored under ultralow oxygen in two temperatures during nine months plus seven days of shelf life.

metabolism and ethylene production of the fruit stored under $0.8 \mathrm{kPa} \mathrm{O}_{2}+1.6 \mathrm{kPa} \mathrm{CO}_{2}$ (Fig. 3a, b). The elevation of storage temperature caused a higher IEC in the fruit stored under $1.2 \mathrm{kPa} \mathrm{O}_{2}+2.0 \mathrm{kPa} \mathrm{CO}_{2}$. The high IEC is related to the postclimacteric state (Bender et al. 2000). Apples stored under $1.2 \mathrm{kPa} \mathrm{O}_{2}+2.0 \mathrm{kPa} \mathrm{CO}_{2}$ at $1.5{ }^{\circ} \mathrm{C}$ had lower IEC than to $1.0^{\circ} \mathrm{C}$, evidencing that they could already have passed by climacteric stage. On the other hand, fruit maintained under 
$0.8 \mathrm{kPaO}_{2}+1.6 \mathrm{kPa} \mathrm{CO}_{2}$ had the lowest IEC and ethylene production at $1.0^{\circ} \mathrm{C}$ (Fig. 3a). For 'Galaxy' apples, the storage under $1.2 \mathrm{kPaO}_{2}+2.0 \mathrm{kPaCO}_{2}$ resulted in higher IEC compared to a $0.8 \mathrm{kPaO}_{2}+1.6 \mathrm{kPaCO}_{2}$ and $0.4 \mathrm{kPa} \mathrm{O}_{2}+1.2 \mathrm{kPaCO}_{2}$ at $1.0{ }^{\circ} \mathrm{C}$. After the period of shelf life, the conditions of $0.4 \mathrm{kPa}+1.2 \mathrm{kPaCO}_{2}$ and $0.8 \mathrm{kPa} \mathrm{O}+1.6 \mathrm{kPaCO}_{2}$ presented a lower IEC than $1.2 \mathrm{kPaO}_{2}+2.0 \mathrm{kPa} \mathrm{CO}_{2}$ at $1.0^{\circ} \mathrm{C}$ (Fig. 3b).

'Royal Gala' apples stored under $0.8 \mathrm{kPa} \mathrm{O}_{2}+1.6 \mathrm{kPa} \mathrm{CO}_{2}$ at $1.0{ }^{\circ} \mathrm{C}$ had lower ACC oxidase activity in relation to $1.2 \mathrm{kPa} \mathrm{O}_{2}+2.0 \mathrm{kPa} \mathrm{CO}_{2}$ (Fig. 3a). At $1.5^{\circ} \mathrm{C}$, the low oxygen did not reduce the activity of the ACC oxidase. When comparing the storage temperatures, the lowest ACC oxidase activity was observed at $1.5^{\circ} \mathrm{C}$ when fruit were submitted to $1.2 \mathrm{kPaO}_{2}+2.0 \mathrm{kPa} \mathrm{CO}$. For 'Galaxy' apples, the lowest activity of ACC oxidase was observed in the fruit under $0.4 \mathrm{kPaO}_{2}+1.2 \mathrm{kPa} \mathrm{CO}_{2}$ condition (Fig. 3b). This lower activity led to a lower ethylene production and lower respiration rate (Fig. 3a).

\section{Flesh firmness, physiological disorders and healthy fruit}

Flesh firmness in 'Royal Gala' apples was higher at $1.5^{\circ} \mathrm{C}$ than at $1.0^{\circ} \mathrm{C}$ (Fig. 2a). Among the storage conditions, the highest flesh firmness was observed under $0.8 \mathrm{kPa} \mathrm{O}_{2}+1.6 \mathrm{kPa} \mathrm{CO}_{2}$, which may be due to the lower ACC oxidase enzyme activity and lower ethylene production (Fig. 2a, 3a). Ethylene activates enzymes that degrade the cell wall (Payasi et al. 2009; Prasanna et al. 2007), causing higher loss of flesh firmness during storage, such as $\beta$-galactosidase, $\alpha$ - 1 -arabinofuranosidase, pectin methyl esterase and polygalacturonase (Ortiz et al. 2011; Wei et al. 2010). For 'Galaxy' apples, the higher flesh firmness maintenance was found under $0.4 \mathrm{kPa} \mathrm{O}_{2}+1.2 \mathrm{kPa} \mathrm{CO}_{2}$ when compared to all the other CA conditions at $1.0^{\circ} \mathrm{C}$. Similar results were found in 'Royal Gala' apples stored under extremely low oxygen partial pressure, where the low oxygen $\left(0.4 \mathrm{kPa} \mathrm{O}+1.2 \mathrm{kPa} \mathrm{CO}_{2}\right)$ maintained higher flesh firmness as compared to $1.2 \mathrm{kPa} \mathrm{O}_{2}+2.0 \mathrm{kPa} \mathrm{CO}_{2}$ storage (Berghetti et al. 2020). This may be related to the higher production of ethanol (Fig. 4a), which reduces the ACC oxidase enzyme activity and the ethylene production. However, when the fruit were stored at $1.5^{\circ} \mathrm{C}$, no difference between the storage conditions was found in ACC oxidase activity. For 'Galaxy' apples, the highest maintenance of flesh firmness was found in the fruit stored under $0.8 \mathrm{kPa} \mathrm{O}_{2}$ at $1.5^{\circ} \mathrm{C}$ (Fig. 2a). The increase of the temperature resulted in a greater flesh firmness maintenance of 'Galaxy' apples stored under DCA-QR 1.3 (Both et al. 2018), and in 'Gala' and 'Imperial Gala' stored under CA ( $1.8 \mathrm{kPa}$ of $\mathrm{O}_{2}+2.0 \mathrm{kPa}$ of $\mathrm{CO}_{2}$ ) (Mazzurana et al. 2016).

The incidence of mealiness is one of the main troubles of the 'Gala' apples group and it is responsible for causing commercial depreciation. This is correlated to the advancement of ripening and degradation of the cell's lamella. The CA condition did not influence the incidence of mealiness for 'Royal Gala' apples (Fig. 2a); however, a lower percentage of mealiness was found at temperature of $1.5^{\circ} \mathrm{C}$ than at $1.0{ }^{\circ} \mathrm{C}$ (Fig. 2a). On the other hand, 'Galaxy' apple submitted to $0.4 \mathrm{kPa} \mathrm{O}_{2}+1.2 \mathrm{kPa} \mathrm{CO}_{2}$ presented lower incidence of mealiness than in any of the other CA conditions, due to a lower activity of the ACC oxidase enzyme, internal ethylene concentration and lower ethylene production at chamber opening and at 7 days of shelf life (Fig. 3a, b).

Flesh breakdown is also correlated to the advancement of ripening and is caused by the leakage of the vacuole content rich in polyphenols that encounters the polyphenol oxidase enzyme of the cell cytosol causing dark color in the pulp. Flesh breakdown may be induced by several factors, such as high concentration of anaerobic metabolism compounds, $\mathrm{CO}_{2}$ concentration above $1 \%$ and cell freezing (Fan et al. 2011; James and Jobling 2009). The incidence of flesh breakdown in 'Royal Gala' apples was lower at $1.5^{\circ} \mathrm{C}$ than at $1.0^{\circ} \mathrm{C}$. Increase in the temperature from 0 to $3{ }^{\circ} \mathrm{C}$ reduced the occurrence of flesh breakdown in 'Pink Lady' (James et al. 2005) and 'Nicoter' apples (Weber et al. 2019). The greater incidence of flesh breakdown may be correlated to the production of ethylene under low-temperature storage (Fig. 1). No significant difference was found in the incidence of flesh breakdown between the different temperatures and CA conditions for 'Galaxy' apples.

The percentage of healthy fruit in 'Royal Gala' was higher at $1.5^{\circ} \mathrm{C}$ than at $1.0^{\circ} \mathrm{C}$ (Fig. 2b), due to the lower incidence of flesh breakdown and mealiness in comparison to fruit stored at $1.0^{\circ} \mathrm{C}$ (Fig. 2a). No difference was found regarding the percentage of healthy fruit, pulp cracking and decay incidence for 'Galaxy' apples. This result suggests that the temperature of $1.5^{\circ} \mathrm{C}$ can be used in apple fruit industry. 


\section{Soluble solids and titratable acidity}

Soluble solids (SS) are a feature that directly influences the consumers acceptance of apples. For 'Royal Gala' apples, the amount of SS after the shelf life period was greater at $1.5^{\circ} \mathrm{C}$ than at $1.0^{\circ} \mathrm{C}$ (Fig. 4a). For 'Galaxy' apples, there was no difference in amount of SS, regardless of the condition and temperature of storage.

\section{Anaerobic metabolism}

Fruit anaerobic metabolism may occur during the storage of apples in ULO, along with the production of anaerobic metabolic compounds such as ethanol, acetaldehyde and ethyl acetate.

For 'Royal Gala' apples, the concentration of ethanol was greater under $0.8 \mathrm{kPa} \mathrm{O}_{2}+1.6 \mathrm{kPa} \mathrm{CO}_{2}$ than in $1.2 \mathrm{kPa} \mathrm{O}_{2}$ $+2.0 \mathrm{kPa} \mathrm{CO}{ }_{2}$ at $1.5^{\circ} \mathrm{C}$ (Fig. $4 \mathrm{~b}$ ), probably because the fruit stored under lower oxygen partial pressure activated more anaerobic metabolism, producing more ethanol. The acetaldehyde concentration was lower under $0.8 \mathrm{kPa} \mathrm{O}_{2}+1.6 \mathrm{kPaCO}_{2}$ when compared to $1.2 \mathrm{kPaO}_{2}+2.0 \mathrm{kPa} \mathrm{CO}_{2}$ at $1.0^{\circ} \mathrm{C}$ (Fig. 4b). The accumulation of acetaldehyde in the fruit tissue can be a response to fruit senescence (Ke et al. 1994; Wright et al. 2015). A greater incidence of mealiness occurred under $1.2 \mathrm{kPa} \mathrm{O}_{2}+2.0 \mathrm{kPaCO}_{2}$ condition, which reduces the diffusion of gases (Brackmann et al. 2014) and consequently induces the production of acetaldehyde (Thewes et al. 2017b). Additionally, fruit kept at $0.8 \mathrm{kPa} \mathrm{O}_{2}+1.6 \mathrm{kPa} \mathrm{CO}_{2}$ probably had a lower pyruvate decarboxylase enzyme (PDC) expression and activity, which is induced by the ethylene (Harb et al. 2011). Therefore, the lower ethylene production was observed in the fruit stored under $0.8 \mathrm{kPa} \mathrm{O}_{2}+1.6 \mathrm{kPa} \mathrm{CO}_{2}$ (Fig. 3a).

Nevertheless, for 'Royal Gala' apples, an inverse response was noticed at $1.5^{\circ} \mathrm{C}$ since the fruit stored under $1.2 \mathrm{kPa}_{2}$ $+2.0 \mathrm{kPa} \mathrm{CO}$ presented a lower concentration of acetaldehyde in comparison to $0.8 \mathrm{kPa} \mathrm{O}_{2}+1.6 \mathrm{kPa} \mathrm{CO}_{2}$. The storage under extremely low oxygen partial pressure results in an increased production of anaerobic metabolism compounds, including an elevated acetaldehyde concentration (Pesis 2005); however, a lower concentration of acetaldehyde was found under $0.8 \mathrm{kPaO}_{2}+1.6 \mathrm{kPa} \mathrm{CO}_{2}$ at $1.0^{\circ} \mathrm{C}$ in comparison to $1.5^{\circ} \mathrm{C}$. The use of low partial pressure of $\mathrm{O}_{2}$ associated with low temperature probably caused damage to the tissue and, consequently, increased the occurrence of physiological disorders such as mealiness and flesh breakdown, besides reducing the flesh firmness (Fig. 2a).

The concentration of ethyl acetate has an important role in the formation of the aroma of apples; however, when present in high concentrations, it can cause off-flavors (Wright et al. 2015). The concentration of ethyl acetate was greater under $1.2 \mathrm{kPaO}_{2}+2.0 \mathrm{kPa} \mathrm{CO}_{2}$ than under $0.8 \mathrm{kPa} \mathrm{O}_{2}+1.6 \mathrm{kPa} \mathrm{CO}_{2}$ for 'Royal Gala', when stored at $1.0{ }^{\circ} \mathrm{C}$ (Fig. 4a). This is due to the fact that there is a higher production of acetaldehyde and ethanol under $1.2 \mathrm{kPa} \mathrm{O}_{2}+2.0 \mathrm{kPa} \mathrm{CO}_{2}$ (Fig. 4a), since the acetaldehyde is converted into ethanol by the $\mathrm{ADH}$ and, from an esterification reaction with acetic acid, forms ethyl acetate (Ke et al. 1994; Lee et al. 2014). However, at $1.5^{\circ} \mathrm{C}$, the condition of $0.8 \mathrm{kPa} \mathrm{O}_{2}+1.6 \mathrm{kPa} \mathrm{CO}$ provided a greater concentration of ethyl acetate than $1.2 \mathrm{kPa} \mathrm{O}_{2}+2.0 \mathrm{kPa} \mathrm{CO}_{2}$ (Fig. 4a). When stored under $0.8 \mathrm{kPa} \mathrm{O}_{2}+1.6 \mathrm{kPa} \mathrm{CO}_{2}$, a greater concentration of ethyl acetate occurred at $1.5^{\circ} \mathrm{C}$ in relation to $1.0^{\circ} \mathrm{C}$.

The lowest concentration of ethanol for 'Galaxy' apples was found under $0.4 \mathrm{kPa} \mathrm{O}_{2}+1.2 \mathrm{kPa} \mathrm{CO}_{2}$, at $1.0^{\circ} \mathrm{C}$, in comparison to $1.2 \mathrm{kPaO}_{2}+2.0 \mathrm{kPa} \mathrm{CO}_{2}$, without differing from $0.8 \mathrm{kPa} \mathrm{O}_{2}+1.6 \mathrm{kPa} \mathrm{CO}_{2}$, probably due to the lower conversion of acetaldehyde into ethanol under $0.4 \mathrm{kPa} \mathrm{O}_{2}+1.2 \mathrm{kPa} \mathrm{CO}_{2}$ (Fig. 4a). However, when 'Galaxy' were stored at $1.5^{\circ} \mathrm{C}$, an inverse response was observed in the conditions of $0.4 \mathrm{kPaO}_{2}+1.2 \mathrm{kPa} \mathrm{CO}_{2}$ and $0.8 \mathrm{kPa} \mathrm{O}_{2}+1.6 \mathrm{kPaCO}_{2}$, the fruit presented greater concentration of ethanol than in $1.2 \mathrm{kPa} \mathrm{O}_{2}+2.0 \mathrm{kPa} \mathrm{CO}_{2}$, due to a larger production of acetaldehyde, that was converted into ethanol by the action of the $\mathrm{ADH}$ enzyme. However, the elevated production of acetaldehyde is due to the anaerobic metabolism and not due to the senescence of the fruit, since these had a lower respiration rate and a lower percentage of mealiness (Fig. 2a, 3a).

A lower concentration of ethanol was noticed when the fruit were stored under $0.8 \mathrm{kPa} \mathrm{O}_{2}+1.6 \mathrm{kPa} \mathrm{CO}_{2}$ at $1.0^{\circ} \mathrm{C}$ than when submitted to $1.5^{\circ} \mathrm{C}$. A similar response was found when the fruit were stored under $0.4 \mathrm{kPa}_{2}+1.2 \mathrm{kPa} \mathrm{CO}_{2}$ at $1.0^{\circ} \mathrm{C}$. The temperature increase from $1.0^{\circ} \mathrm{C}$ to $18{ }^{\circ} \mathrm{C}$ resulted in a more than 10 -fold increase in the anaerobic metabolism in apples fruit (Boeckx et al. 2018). Another related factor is the chilling injury combined with low oxygen partial pressure (Brackmann et al. 2012). Fruit stored under $1.2 \mathrm{kPaO}_{2}+2.0 \mathrm{kPaCO}_{2}$ presented the lowest concentration of acetaldehyde in comparison to all the other storage conditions. 


\section{CONCLUSION}

The best storage condition for 'Royal Gala' apples is $0.8 \mathrm{kPa} \mathrm{O}_{2}+1.6 \mathrm{kPa} \mathrm{CO}_{2}$ at $1.5{ }^{\circ} \mathrm{C}$, which maintains a higher percentage of healthy fruit, soluble solids, flesh firmness, lower flesh breakdown and mealiness. However, lower $\mathrm{O}_{2}$ partial pressures, such as $0.4 \mathrm{kPa}$, should be studied for this cultivar in the future.

For 'Galaxy' apples the storage under $0.4 \mathrm{kPaO}_{2}+1.2 \mathrm{kPaCO}_{2}$ at $1.5^{\circ} \mathrm{C}$ was the most efficient, because it reduces the ACC oxidase enzyme activity, along with the ethylene production and decreases the incidence of mealiness. The temperature can be increased from $1{ }^{\circ} \mathrm{C}$, which is traditionally used for these mutants, to the temperature of $1.5^{\circ} \mathrm{C}$, which can allow saving electrical energy.

There was an increase in the ethanol concentration by increasing the temperature from 1.0 to $1.5^{\circ} \mathrm{C}$ for 'Galaxy' and 'Royal Gala' apples stored under $0.4 \mathrm{kPa} \mathrm{O}_{2}+1.2 \mathrm{kPa} \mathrm{CO}_{2}$ conditions. 'Galaxy' apples stored under $0.4 \mathrm{kPa} \mathrm{O}_{2}+1.2 \mathrm{kPa}$ $\mathrm{CO}_{2}$ and $0.8 \mathrm{kPaO}_{2}+1.6 \mathrm{kPaCO}_{2}$ results in higher concentration of ethanol compared to $1.2 \mathrm{kPa} \mathrm{O}_{2}+2.0 \mathrm{kPa} \mathrm{CO}_{2}$.

\section{FUNDERS}

Conselho Nacional de Desenvolvimento Científico e Tecnológico

[http://doi.org/10.13039/501100003593]

Grant \#305737/2013-9

\section{AUTHOR'S CONTRIBUTION}

Conceptualization, Ludwig V., Berghetti M. R. P., Brackmann A., Thewes F. R., Wendt, L. M.; Methodology, Wendt, L. M. and Schultz E. E.; Investigation, Ludwig V., Brackmann A. and Thewes F. R.; Writing - Original Draft, Ludwig V., Thewes F. R.; Writing - Review and Editing, Brackmann A., Thewes F. R., Berghetti M. R. P., Schultz E. E. and Schmidt S. F. P., Funding Acquisition, Brackmann A.; Resources, Brackmann A.; Supervision, Brackmann A., Thewes F. R.

\section{REFERENCES}

[AGAPOMI] Associação Gaúcha dos Produtores de Maçã (2018). [Accessed Set. 27, 2019]. Available at: http://agapomi.com.br/ informacoes/dados-estatisticos/

Álvarez-Hernández, M. H., Martínez-Hernández, G. B., Avalos-Belmontes, F., Castillo-Campohermoso, M. A., Contreras-Esquivel, J. C. and Artés-Hernández, F. (2019). Potassium Permanganate-Based Ethylene Scavengers for Fresh Horticultural Produce as an Active Packaging. Food Engineering Reviews, 11, 159-183. https://doi.org/10.1007/s12393-019-09193-0

Anese, R. O., Brackmann, A., Wendt, L. M., Thewes, F. R., Schultz, E. E., Ludwig, V. and Berghetti, M. R. P. (2019). Interaction of 1-methylcyclopropene, temperature and dynamic controlled atmosphere by respiratory quotient on 'Galaxy’ apples storage. Food Packaging and Shelf Life, 20, 100246. https://doi.org/10.1016/j.fpsl.2018.07.004

Antoniolli, L. R., Nachtigall, G. R., Nava, G., Fialho, F. B., Santos, H. P. and Dechen, A. R. (2011). Qualidade de maçãs baseada nas condições nutricionais e meteorológicas. G. R. Nachtgall (Ed). Inovações tecnologicas para o setor da maçã. Bento Gonçalves: Embrapa Uva e Vinho.

Argenta, L. C. and Brackmann, A. (1994). Qualidade pós-colheita de maçãs armazenadas sob diferentes temperaturas e concentraçoes de $\mathrm{CO}_{2}$ e $\mathrm{O}_{2}$. Revista Brasileira de Fisiologia Vegetal, 6, 121-126.

Asoda, T., Terai, H., Kato, M. and Suzuki, Y. (2009). Effects of postharvest ethanol vapor treatment on ethylene responsiveness in broccoli. Postharvest Biology and Technology, 52, 216-220. https://doi.org/10.1016/j.postharvbio.2008.09.015 
Bekele, E. A., Ampofo-Asiama, J., Alis, R. R., Hertog, M. L. A. T. M., Nicolai, B. M. and Geeraerd, A. H. (2016). Dynamics of metabolic adaptation during initiation of controlled atmosphere storage of 'Jonagold' apple: Effects of storage gas concentrations and conditioning. Postharvest Biology and Technology, 117, 9-20. https://doi.org/10.1016/j.postharvbio.2016.02.003

Bender, R. J., Brecht, J. K., Baldwin E. A. and Malundo, T. M. M., (2000). Aroma Volatiles of Mature-green and Tree-ripe 'Tommy Atkins' Mangoes after Controlled Atmosphere vs. Air Storage. HortScience, 35, 684-686. https://doi.org/10.21273/HORTSCI.35.4.684

Berghetti, M. R. P., Brackmann, A., Thewes, F. R., Schultz, E. E., Ludwig, V., Wendt, L. M., Thewes, F. R. and Schmidt, S. F. P., (2020). Extremely low oxygen partial pressures for the storage of 'Royal Gala' apple. Bragantia, 79, 145-154. https://doi.org/10.1590/1678-4499.20190016

Boeckx, J., Hertog, M. L. A. T. M., Geeraerd, A. H. and Nicolaï, B. M. (2018). Balancing between respiration and fermentation. Acta Horticulturae, 1194, 689-694. https://doi.org/10.17660/ActaHortic.2018.1194.98

Boersig, M. R., Kader, A. A. and Romani, R. J. (1988). Aerobic-anaerobic respiratory transition in pear fruit and cultured pear fruit cells. American Society for Horticultural Science, 113, 869-873.

Both, V., Brackmann, A., Thewes, F. R., Ferreira, D. F. and Wagner, R. (2014 a). Effect of storage under extremely low oxygen on the volatile composition of 'Royal Gala’ apples. Food Chemistry, 156, 50-57. https://doi.org/10.1016/j.foodchem.2014.01.094

Both, V., Brackmann, A., Thewes, F. R., Weber, A., Schultz, E. E. and Ludwig, V. (2018). The influence of temperature and 1-MCP on quality attributes of ‘Galaxy' apples stored in controlled atmosphere and dynamic controlled atmosphere. Food Packaging and Shelf Life, 16, 168-177. https://doi.org/10.1016/j.fpsl.2018.03.010

Both, V., Brackmann, A., Weber, A., Anese, R. O. and Thewes, F. R. (2014 b). Estresse inicial por baixo oxigênio seguido do armazenamento em atmosfera controlada de maçãs ‘Royal Gala'. Revista Ciência Agronômica, 45, 708-717. https://doi.org/10.1590/S1806-66902014000400008

Both, V., Thewes, F. R., Brackmann, A., Anese, R. O., Ferreira, D. F. and Wagner, R. (2017). Effects of dynamic controlled atmosphere by respiratory quotient on some quality parameters and volatile profile of 'Royal Gala' apple after long-term storage. Food Chemistry, 215, 483-492. https://doi.org/10.1016/j.foodchem.2016.08.009

Brackmann, A., Both, V., Pavanello, E. P., Anese, R. O. and Santos, J. R. A. (2013). Atmosfera controlada, absorção de etileno e aplicação de 1-MCP durante o armazenamento de pêssegos ‘Eragil'. Científica, 41, 156-163.

Brackmann, A., Both, V., Pinto, J. A. V., Weber, A. and Pavanello, E. P. (2009). Absorção de 1-metilciclopropeno aplicado em maçãs 'Royal Gala' armazenadas em atmosfera refrigerada juntamente com madeira. Ciência Rural,39,1676-1681. https://doi.org/10.1590/S0103-84782009005000108

Brackmann, A., Both, V., Weber, A., Pavanello, E. P., Schorr, M. R. W. and Santos, J. R. A. (2012). Changes in temperature, oxygen and $\mathrm{CO}_{2}$ during controlled atmosphere storage of 'Royal Gala' apples. Semina: Ciências Agrárias, 33, 2247-2256. https://doi. org/10.5433/1679-0359.2012v33n6p2247

Brackmann, A., Thewes, F. R., Anese, R. O. and Both, V. (2014). Effect of growth regulators on 'Brookfield' apple gas diffusion and metabolism under controlled atmosphere storage. Pesquisa Agropecuária Brasileira, 49, 323-329. https://doi.org/10.1590/S0100-204X2014000500001

Brackmann, A., Waclawovsky, A. J. and Lunardi, R. (2000). Qualidade de maçãs cv. Gala armazenadas em diferentes pressões parciais de $\mathrm{O}_{2}$ eCO $_{2}$. Scientia Agricola, 57, 195-198. https://doi.org/10.1590/S0103-90162000000200001

Brackmann, A., Weber, A., Giehl, R. F. H., Ana Cristina Eisermann, A. C., Sautter, C. K., Gonçes, E. D. and Antunes, L. E. C. (2010). Armazenamento de mirtilo ‘Bluegem’ em atmosfera controlada e refrigerada com absorção e inibição do etileno. Revista Ceres, 57, 6-11. https://doi.org/10.1590/S0034-737X2010000100002

Brackmann, A., Weber, A., Pinto, J. A. V., Neuwald, D. A. and Steffens, C. A. (2008). Manutenção da qualidade pós-colheita de maçãs ‘Royal Gala’ e ‘Galaxy’ sob armazenamento em atmosfera controlada. Ciência Rural, 38, 2478-2484. https://doi.org/10.1590/ S0103-84782008000900010 
Bufler, G. (1986). Ethylene-promoted conversion of 1-aminocyclopropane-1-carboxylic acid to ethylene in peel of apple at various stages of fruit development. Plant Physiology, 80, 539-543. https://doi.org/10.1104/pp.80.2.539

Bulens, I., Van de Poel, B., Hertog, M. L. A. T. M., De Proft, M. P., Geeraerd, A. H. and Nicolai, B. M. (2012). Influence of harvest time and 1-MCP application on postharvest ripening and ethylene biosynthesis of 'Jonagold' apple. Postharvest Biology and Technology, 72, 11-19. https://doi.org/10.1016/j.postharvbio.2012.05.002

Fan, L., Song, J., Forney, C. F. and Jordan, M. A. (2011). Fruit maturity affects the response of apples to heat stress. Postharvest Biology and Technology, 62, 35-42. https://doi.org/10.1016/j.postharvbio.2011.04.007

Gorny, J. R. and Kader, A. A. (1996). Controlled-atmosphere suppression of ACC synthase and ACC oxidase in 'Golden Delicious' apples during long-term cold storage. Journal of the American Society for Horticultural Science, 121, 751-755. https://doi.org/10.21273/ JASHS.121.4.751

Harb, J., Lara, I., Saleh, O., Streif, J. and Khraiwesh, B. (2011). Treatments that suppress ethylene production or ethylene action modify $A D H$ and $A A T$ gene expression and aroma-related enzyme activities in 'Delbarde Estivale' apple: consequences for the aroma profiles of fruit. The Journal of Horticultural Science and Biotechnology, 86, 182-188. https://doi.org/10.1080/14620316.2011.11512745

Imahori, Y., Yamamoto, K., Tanaka, H. and Bai, J. (2013). Residual effects of low oxygen storage of mature green fruit on ripening processes and ester biosynthesis during ripening in bananas. Postharvest Biology and Technology, 77, 19-27. https://doi.org/10.1016/j. postharvbio.2012.11.004

James, H. J. and Jobling, J. J. (2009). Contrasting the structure and morphology of the radial and diffuse flesh browning disorders and $\mathrm{CO}_{2}$ injury of ‘Cripps Pink' apples. Postharvest Biology and Technology, 53, 36-42. https://doi.org/10.1016/j.postharvbio.2009.02.001

James, H., Brown, G., Mitchan, E., Tanner, D., Tustin, S., Wilkinson, I., Zanella, A. and Jobling, J. (2005). Flesh browning in Pink Lady ${ }^{\text {TM }}$ apples: research results have helped to change market specifications for blush colour which is an added bonus for growers. Acta Horticulturae, 687, 175-180. https://doi.org/10.17660/ActaHortic.2005.687.20

Ke, D., Rodriguez-Sinobas, L. and Kader, A. A. (1991). Physiology and prediction of fruit tolerance to low-oxygen atmospheres. Journal of the American Society for Horticultural Science, 116, 253-260. https://doi.org/10.21273/JASHS.116.2.253

Ke, D., Yahia, E., Mateos, M. and Kader, A. A. (1994). Ethanolic fermentation of 'Bartlett' pears as influenced by ripening stage and atmospheric composition. Journal of the American Society for Horticultural Science, 119, 976-982. https://doi.org/10.21273/JASHS.119.5.976

Kittemann, D., McCormick, R. and Neuwald, D. A. (2015). Effect of high temperature and 1-MCP application or dynamic controlled atmosphere on energy savings during apple storage. European Journal of Horticultural Science, 80, 33-38. https://doi.org/10.17660/eJHS.2015/80.1.5

Köpcke, D. (2015). 1-Methylcyclopropene (1-MCP) and dynamic controlled atmosphere (DCA) applications under elevated storage temperatures: Effects on fruit quality of ‘Elstar', 'Jonagold' and 'Gloster' apple (Malus domestica Borkh.). European Journal of Horticultural Science, 80, 25-32. https://doi.org/10.17660/eJHS.2015/80.1.4

Kruse, J., Rennenberg, H. and Adams, M. A. (2011). Steps towards a mechanistic understanding of respiratory temperature responses [Special Issue]. New Phytologist, 189, 659-677. https://doi.org/10.1111/j.1469-8137.2010.03576.x

Lee, J., Rudell, D. R. and Watkins, C. B. (2014). Metabolic changes in 1-methylcyclopropene (1-MCP)-treated 'Empire' apple at different storage temperatures. Acta Horticulturae, 1048, 113-119. https://doi.org/10.17660/ActaHortic.2014.1048.13

Lumpkin, C., Fellman, J. K., Rudell, D. R. and Mattheis, J. P. (2015). 'Fuji’ apple (Malus domestica Borkh.) volatile production during high $\mathrm{pCO}_{2}$ controlled atmosphere storage. Postharvest Biology and Technology, 100, 234-243. https://doi.org/10.1016/j.postharvbio.2014.10.008

Mazzurana, E. R., Argenta, L. C., Amarante, C. V. T. and Steffens, C. A. (2016). Potenciais benefícios do aumento da temperatura de armazenagem em atmosfera controlada de maçãs ‘Gala’ tratadas com 1-MCP. Revista. Brasileira de Fruticultura, 38, 43-52. https://doi. org/10.1590/0100-2945-237/14 
Mditshwa, A., Fawole, O. A., Vries, F., van der Merwe, K., Crouch, E. and Opara, U. L. (2017). Minimum exposure period for dynamic controlled atmospheres to control superficial scald in 'Granny Smith' apples for long distance supply chains. Postharvest Biology and Technology, 127, 27-34. https://doi.org/10.1016/j.postharvbio.2016.12.009

Ortiz, A., Graell, J. and Lara, I. (2011). Cell wall-modifying enzymes and firmness loss in ripening ‘Golden Reinders’ apples: A comparison between calcium dips and ULO storage. Food Chemistry, 128, 1072-1079. https://doi.org/10.1016/j.foodchem.2011.04.016

Payasi, A., Mishra, N. N., Chaves, A. L. S. and Singh, R. (2009). Biochemistry of fruit softening: an overview. Physiology and Molecular Biology of Plants, 15, 103-113. https://doi.org/10.1007/s12298-009-0012-z

Pesis, E. (2005). The role of the anaerobic metabolites, acetaldehyde and ethanol, in fruit ripening, enhancement of fruit quality and fruit deterioration. Postharvest Biology and Technology, 37, 1-19. https://doi.org/10.1016/j.postharvbio.2005.03.001

Podd, L. A. and Van Staden, J. (1998). The role of ethanol and acetaldehyde in flower senescence and fruit ripening - a review. Plant Growth Regulation, 26, 183-189. https://doi.org/10.1023/A:1006131517539

Prasanna, V., Prabha, T. N. and Tharanathan, R. N. (2007). Fruit ripening phenomena - an overview. Critical Reviews in Food Science and Nutrition, 47, 1-19. https://doi.org/10.1080/10408390600976841

Saltveit, M. E. (1999). Effect of ethylene on quality of fresh fruits and vegetables. Postharvest Biology and Technology, 15, 279-292. https:// doi.org/10.1016/S0925-5214(98)00091-X

Steffens, C. A., Brackmann, A., Pinto, J. A. V. and Eisermann, A. C. (2007). Taxa respiratória de frutas de clima temperado. Pesquisa Agropecuária Brasileira, 42, 313-321. https://doi.org/10.1590/S0100-204X2007000300003

Thewes, F. R., Both, V., Brackmann, A., Weber, A. and Anese, R. O. (2015). Dynamic controlled atmosphere and ultralow oxygen storage on 'Gala' mutants quality maintenance. Food Chemistry, 188, 62-70. https://doi.org/10.1016/j.foodchem.2015.04.128

Thewes, F. R., Brackmann, A., Anese, O. R., Bronzatto, E. S., Schultz, E. E. and Wagner, R. (2017b). Dynamic controlled atmosphere storage suppresses metabolism and enhances volatile concentrations of 'Galaxy' apple harvested at three maturity stages. Postharvest Biology and Technology, 127, 1-13. https://doi.org/10.1016/j.postharvbio.2017.01.002

Thewes, F. R., Brackmann, A., Anese, R. O., Ludwig, V., Schultz, E. E., Santos, L. F. and Wendt, L. M. (2017a). Effect of dynamic controlled atmosphere monitored by respiratory quotient and 1-methylcyclopropene on the metabolism and quality of 'Galaxy' apple harvested at three maturity stages. Food Chemistry, 222, 84-93. https://doi.org/10.1016/j.foodchem.2016.12.009

Watkins, C. B. (2008). Dynamic controlled atmosphere storage - a new technology for the New York storage industry? New York Fruit Quality, 16, 23-26.

Weber, A., Brackmann, A., Anese, R. O., Both, V. and Pavanello, E. P. (2013). Atmosfera controlada para o armazenamento da maçã 'Maxi Gala'. Revista Ciência Agronômica, 44, 294-301. https://doi.org/10.1590/S1806-66902013000200011

Weber, A., Thewes, F. R., Sellwig, M., Brackmann, A., Wünsche, J. N., Kittemann, D. and Neuwald, D. A., (2019). Dynamic controlled atmosphere: Impact of elevated storage temperature on anaerobic metabolism and quality of 'Nicoter' apples. Food Chemistry, 298, 125017. https://doi.org/10.1016/j.foodchem.2019.125017

Wei, J., Ma, F., Shi, S., Qi, X., Zhu, X. and Yuan, J. (2010). Changes and postharvest regulation of activity and gene expression of enzymes related to cell wall degradation in ripening apple fruit. Postharvest Biology and Technology, 56, 147-154. https://doi.org/10.1016/j. postharvbio.2009.12.003

Wright, A. H., Delong, J. M., Arul, J. and Prange, R. K. (2015). The trend toward lower oxygen levels during apple (Malus $\times$ domestica Borkh) storage. The Journal of Horticultural Science and Biotechnology, 90, 1-13. https://doi.org/10.1080/14620316.2015.11513146 